\title{
欧米都市における文化生産と「日本らしさ」の構築
}

—ファッション, デザイン, アートの制作者のエスノグラフィー—

\section{藤田 結子*}

\begin{abstract}
本稿は, 文化生産におけるナショナル・アイデンティティの構築について考 察することを目的とする. 考察のため, 「欧米都市のアート・ワールドにおい て，どのような要因により『日本らしさ』の構築が促されているのか」という 研究の問いを設定し, ファッション, インダストリアル・デザイン, 現代アー トの各分野を対象に調査を行った。調査方法にはマルチサイテッド・エスノグ ラフィーを用い, パリ, ロンドン, ニューヨーク, 東京などで参与観察とイン タビューを実施した。

調査の結果, 欧米都市のアート・ワールドでは異なる職業・役割をもつ人々 を結びつける弱い紐帯が, さまざまな利益を生む活動に影響を及ぼしていた。 しかし国境を越える人のフローが活発化し，アジア系のデザイナーやアーティ ストの活動が顕著になっている現在でも, バイヤーやコレクター, 記者・編集 者など重要な判断や権力を行使する職業・役割においては, 白人が多数派を占 めていた. この状況のもと, 白人性を「標準」とした価值観を基に, 日本出身 のデザイナー, アーティストとその作品が本質的な「日本らしさ」と結びつけ られていた。

結論として, 制作者の「日本らしさ」への愛着によってナショナル・アイデ ンティティが再生産されているのではなく, アート・ワールドの職業・役割に 見られる特徵的な人種関係と, その人種関係に基づく作者・作品への評価のあ り方が「日本らしさ」の再構築を促していることが明らかになった.

キーワード：文化生産, アート・ワールド, ナショナル・アイデンティティ
\end{abstract}

\section{1 はじめに}

1990 年代以降, アジアや欧米で日本発の文化的商品が広く普及し, 国境を越え るアニメ, マンガ, ゲームに関する研究が盛んになっている（Allison 2006; Iwabuchi 2002). これらは, 小説, 映画, 音楽などとともに「コンテンツ」と呼ばれ, 印刷・電子メディアを通して流通する情報の形式をとる. それに対して本稿は, こ 
れまで十分に考察がなされてこなかった領域であるファッションやデザイン, アー 卜について検討する。 これらの分野の商品の大半は, 衣服, 日用品・家具, 絵画・ 彫刻など，メディア・コンテンツとは異なる形式をとる，本稿は，グローバル化す るファッションやデザイン, アートの生産過程に注目し, どのように「日本らし さ」が再構築されているのかを考察することを目的とする.

この問題意識の背景には, トランスナショナルな文化とアイデンティティに関す る議論がある。一方で, 国境を越える人, 情報, モノのフローが増加するなか, ナ ショナルな文化の境界が摇らいでいると指摘されている. その一方で,「日本のデ ザイン」「日本ブランド」という表現が多用されるように, ナショナルな文化の 境界が強調される動きもある. このように相反する 2 つ傾向が見られるのは, 在 来型の国民国家の縛りが緩まる一方で, 文化的・民族的に象徴的な場所がより重 要になり「想像の共同体」への愛着が強まるからだと説明できるかもしれない (Giddens 2000)．だがそうであれば，どのようにしてナショナルな文化やアイデン ティティが再構築されているのだろうか. それは制作者の「日本らしさ」への愛着 からくるナショナル・アイデンティティの再生産なのだろうか. 以上の問題意識に 基づき, 本稿はエスノグラフィーを用いて, グローバル化のなか日本らしさ」が 再構築される過程を明らかにしようと試みる.

本稿ではとくにファッション・デザイン，インダストリアル・デザイン，現代ア 一トを調查の対象とする. 本論に入る前に, この 3 分野を選定する理由, および各 分野と「大衆文化」「高級文化」の概念の関係について述べておきたい.

ファッション, インダストリアル, 広告, グラフィックなどのデザイン分野は, しばしばコマーシャル・アートに分類される，本稿では，さまざまなデザイン分野 のうち, とくにファッション・デザイン，インダストリアル・デザインを取り上げ る. なぜならファッションとインダストリアル分野は, クライアントへの従属 （Becker 1982：291）の度合いが比較的高い広告やグラフィック分野よりも, 作家 性を重んじる傾向が強い，デザイナーの名前がブランド名や商品名となる, あるい はデザイナーや作品に対して評論家やメディアが批評を行うなどのケースもよく見 られる。本稿では, 制作者を取り巻く関係や交渉に焦点をあて「日本らしさ」の構 築過程を考察することから, 先の 2 分野が研究の目的に適していると考える.

このようなファッション, インダストリアル分野で制作される商品の大半は大量 複製品であり, 不特定多数の人々の間で消費・受容される. しかしまた, オートク チュールと呼ばれる 1 点ものの高級服など高い経済資本を有する少数の人々に消費 される商品も一部存在する。 したがって, 前者は「大衆文化」, 後者は「高級文化」 とみなすことができるだろう。

他方，現代アートは，ファイン・アートに分類される「高級文化」だといえる. ベンヤミンの複製技術に関する議論の批判的検討が行われ, 現代の文化産業は各種 の複製技術によって芸術作品のアウラまでをも大量に生産していると議論がなされ てきた（吉見 1994: 19）.しかし 1960 年代以降, ポップ・アートの登場によって 
芸術の「高級」性の自己否定が加速し始める.「記号体系としての文化」という視 点が広がり,「高級 /大衆」といった価值判断は解釈の問題とみなされるようにな った（吉澤 2007：173）。 また消費の面から見ると, 現代アートの購入者の大半は 高所得者層だが，とくにポップ・アートは安価な複製商品が多数の人々に消費され ている，最近では，現代アーティストが次々とファッション・デザインに進出する ようにもなっている. したがって, 現代アートは, 現在も art/craftの境界 (Becker 1982: 272）が動的に形成され続けている領域であり，またファイン・アートのな かでもコマーシャル・アートおよび「大衆文化」にもっとも接近している領域の 1 つだといえるだろう。このような現代アートにおける作者の位置づけや共同的な活 動のあり方には, ファッション, インダストリアル分野におけるそれとの共通点が 多く見られる，以上の理由から，本稿では現代アートを調査対象に含める.

以下で，まず研究の問いの理論的枠組みとなる (1)グローバル化のなかのナショナ ルな文化とアイデンティティ, (2)文化生産と人種 ${ }^{1)}$, ナショナリティに関する先行 研究を検討する. つぎに調査の目的と方法, 調査結果について述べ, 最後に本稿か ら明らかになった点をまとめたい.

\section{2 先行研究の検討}

\section{1 ナショナルな文化とアイデンティティ}

グローバリゼーションと文化の問題が広く関心を集めるようになったのは，1960 年代の文化帝国主義に関する議論にさかのぼる. とくに 70 年代から 80 年代, 「情 報や大衆文化のフローが欧米諸国から第 3 世界への一方通行になっている」という フローの構造と,「ローカル文化が西洋化されていく」という文化的影響が問題と されていた (Schiller 1969). しかし80 年代半ばから, 社会学や文化人類学でより 慎重な議論が増え始める。ローカル文化は同質化に対する抵抗力をもつとみなされ, 「クレオール化」「グローカル化」などの用語が生み出されてきた（Hannerz 1992; Pieterse 1995).さらに 90 年代には, ナショナルな文化やアイデンティティの自明 性を問う議論が活発になる。前記の先行研究においても, ローカル文化とは, 事実 上ナショナルなものを意味する場合が多かった．しかし 90 年代以降，「トランスナ ショナリズム」の概念が広まり，ナショナルな境界はより批判的に検討されるよう になる，そのおもな議論によると，交通手段の技術的発達・低価格化，コミュニケ ーション技術の発展により, 国境を越えてネットワークやコミュニティが形成され るようになった，多くの人々が越境空間に生きるようになり，トランスナショナル なネットワークや組織の勢力が増し始めた（Basch et al. 1994; Sassen 2001）。その 結果, ネイションが第一義的なアイデンティティや共同体である時代は終わりを迎 えつつあるという (Castells 1997).

この議論が発展し, アメリカの移民研究やイギリスの文化研究で, トランスナシ ヨナル・アイデンティティの形成に大きな関心が寄せられている.これは抽象的な 
概念で論者によって定義が異なるが，共通して「1つのネイションへの帰属意識を 超える多層的・多元的な意識」という点を含んでいる（Waters 1999）.さらには, アメリカ合衆国という場所には「アメリカ文化」がある, というようなナショナル な文化の境界も問い直されるようになり, トランスナショナル文化の出現も報告さ れている (Gupta and Ferguson eds. 1999).

他方で, ナショナルな文化やアイデンティティが再構築されるという傾向も顕著 になっている，そのような傾向は, 第 1 に, 政府主導による上からのクリエイティ ブ産業振興である.イギリスの「クール・ブリタニア」を筆頭に，「クール・コリ ア」「クール・ジャパン」などのナショナル・ブランディングがよく知られている だろう。第 2 に，文化生産の過程で起こる，下からのナショナル・アイデンティテ イの再構築である. 今日では, たとえばあるデザイン商品のデザイナーが日本出身 であっても, 企画はイギリス, 複製品の生産は東欧, 展示はフランス, 販売は世界 各国で行われるというように，複数の地域で分業が行われている．このように文化 的商品の生産過程がグローバル化していく一方で, 制作者や作品のナショナル・ア イデンティティが強調される傾向も指摘されている (Iwabuchi 2002).

\section{2 文化生産と人種, ナショナリティ}

このような文化生産に関する問題を考察するうえで，筆者は，芸術社会学の「制 度的アプローチ」が有用だと考える。 この制度的アプローチは, 作品を 1 人の才能 によって作られるものと捉えず, 人々の間のやりとりや組織の交涉という社会的な 営みや分業を経て作り出され受容されるものとみなし, そのプロセスを中心的な分 析の対象とする（佐藤 1999：10）。この代表的研究者である H.S.ベッカーによれば, アート作品の制作の場合, 道具の製造業者から, それを展示するキュレーターや何 をなすべきか基準を与える評論家までが分業に関与している (Becker 1982: 13).

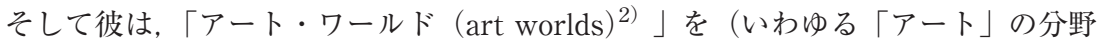
に限定せず)，「作品を制作するのに必要な活動を行う人びとの全員から成り立つも の」としている.さらに,「アート・ワールド」は明確な共同体や組織としての境 界をもたず，構成員の協同的な活動のなかに存在すると述べている（Becker 1982： 34).

ベッカーがA H W W rlds を出版した 1980 年代には, 文化生産における人種やナ ショナリティの問題は十分に検討されていなかった. だが 90 年代になると, 文化 産業と市場のグローバル化が進み, 人種, ナショナリティ, ジェンダー, 階層など の複合的要因が与える影響が問われるようになる。

まずファッションに関しては, パリを主要な「結節点 (node) ${ }^{3)} 」$ (Appadurai 1996: 31）とする文化のフローが形成されている. 世界各国のデザイナーがパリに 集まるのは，ほかの都市ではパリが提供する地位を獲得できないからである．毎年 2 回パリで開催されるショーの時期には，世界中から何千人のバイヤーや編集者・ 記者が集結し, そのなかにはとくにクリエイティビティの評価に影響力をもつ者が 
存在する.デザイナーは, そのような人々から「正統性」を承認されてはじめて, 世界的に認められるデザイナーとなることができる（Kawamura 2004）。だが，そ のような地位付与機能をもつ欧米のファッション界では,「白人」が人種上の刻印 を免れたある種の普遍性を保持している．「有色人種」のデザイナーは人種的に有 標化され，その作品は，個々のデザインの達成度以上に，民族的な美意識や衣装と いう本質的な伝統観に結びつけられてしまう傾向が強い（Kondo 1997）。たとえば 1973 年にイッセイ・ミヤケが, 81 年にコム・デ・ギャルソンとヨウジ・ヤマモト がパリコレクションに参加し始め, この「御三家」は欧米でも高い評価を獲得した. 当時の彼らの作品は, 黒を多用する色使いや斬新な素材・縫製方法とシルエットを 特徵としており，伝統的な日本服飾史には直接関連づけにくい．だが西欧の服飾の 伝統や「女らしさ」の概念から逸脱していたために, 欧米メディアは彼らの作品を 本質的な「日本（人）らしさ」と関連づけて表象してきた（Kondo 1997; Skov 1996)。また欧米メディアは，90 年代以降，原宿の若者のストリート・ファッショ ンを取り上げてきたが，その表象の根底にはオリエンタリズムのまなざしがあると いう（成実 2001）。

現代アートに関しても同様の傾向が見られる．欧米では，スイスやマイアミのア ートバーゼルなど，毎年集客力をもつアートフェアが開催されている．またニュー ヨークやロンドンには世界的に有名なギャラリーや美術館が集結している。これら の場で作品が展示されることによって, メディアに報道され, 美術評論家やコレク ターの間で認知度が高まり, グローバルなアート市場に流通しやすくなる (Thornton 2009)。だが欧米のアート界は保守的な世界であり，キュレーターや美 術評論家などの重要な職業を牛耳っているのは白人男性である（竹沢 2009）。また 欧米の芸術では白人性が審美的な「規範」「標準」として位置づけられている (Dyer 1997：3). 1950 年代にニューヨークへ渡り活動した草間彌生やオノ・ヨー コの場合, 人種とジェンダーによって二重に周縁化され，「エキゾチックな」「受け 身な」日本女性というイメージと結びつけられたという（Yoshimoto 2005：44）.

このステレオタイプ的な「日本（人）らしさ」は，19 世紀以降の「オリエンタ ル」「イエローペリル」など中国系を中心とするアジア系の表象の一部として形成 されてきた. 1980 年代には新たな日本人哈威論が生まれ，日本人ビジネスマンは 「カミカゼ」「サムライ」に関連づけられるようになった，さらに 90 年代以降，テ クノロジーやサブカルチャーに耽溺する「オタク」像が普及していく，その一方で, 日本人女性像は「エキゾチックな」「芸者」から「カワイイ」「制服の女子高生」へ と広がりつつも，19世紀の『蝶々夫人』の時代からつねに性的なイメージと関連 ゔけられてきた。このような欧米での「日本（人）らしさ」の表象は, 日本の歴史 的変化を映し出しているというょりも, 日本に対する欧米の態度を反映したものだ という指摘がなされている（Lee 1999=2007; Yamamoto 1999）. 


\section{3 調査の目的と方法}

以上の先行研究から, 欧米のアート・ワールドでは白人の男性がパワーをもち, 人種，ナショナリティ，ジェンダー，階級が複雑に交差するなかで分業が行われ， ナショナル・アイデンティティが再構築されてきたといえるだろう。しかし今日で は, 先行研究のデザイナーやアーティストが欧米に進出した 1950～80 年代初頭以 上に，文化産業はグローバルな分業システムに依存している．さらに，国境を越え る人のフローも活発化し, 多数の人々が日本から欧米都市に渡り文化的な活動を行 うようになった（藤田 2008）。そこで本稿は，このようなグローバル化よる状況の 変化のなか,「欧米都市のアート・ワールドにおいて，どのような要因により『日 本らしさ』の構築が促されているのか」という研究の問いを設定し考察を行うこと を目的とする. とくに本稿は, 日本出身のデザイナーやアーティストを取り巻く関 係や交渉を中心的な分析の対象とする。また本稿では,「アート・ワールド」とい う語をべッカーが提案した意味で用い, アート界だけでなく, ファッション界 やデザイン゙界ににも応用する。

考察のために，日本から欧米都市に移住し，ファッション・デザイン，インダス トリアル・デザイン，現代アートの分野で長年活動している人々に調査への参加を 依頼した，方法として，まず新聞や専門誌の記事に掲載されていたデザイナー，ア ーティストに連絡を取りインタビューを依頼し, さらにこの人々を通してスノーボ ールサンプリングを行った，その結果, 計 21 名（男 11 名, 女性 10 名）の調査参 加者を集めた．年齢は 30〜 40 代，現地の滞在年数は 10〜30 年程度である.デザイ ナーに関しては会社や事務所を設立している者, アーティストに関しては大手ギャ ラリーに所属している者が大半である。マルチサイテッド・エスノグラフィー (Marcus 1995）を用い, パリ, ロンドン, ニューヨーク, 東京などで, 21 人への 参与観察と継続的なインタビューを行った ${ }^{4)}$. その現場は㧍もに, 調查参加者が活 動しているアトリエ, 展示会, 見本市, ギャラリー, レセプションなどである. そ の際, 彼ら彼女らと関わりのある広報, バイヤー, キュレーター, ディーラー, 記 者などにもインタビューを実施した。この内容をすべてテクストに書き起こし分析 を行った，民族誌は「部分的真実（partial truths）」(Clifford 1986）だと指摘され るように, 本稿も, 特定の社会的コードや自身の属性の制約を受けている筆者が, 調查参加者との相互行為や対話を通して生み出した記述だといえる. そうであれば, 前記の方法のより詳細な内容を公開し自己再帰的なフィールドワークの報告と検討 を行うべきであるが, 字数制限のため本稿では省略せざるをえず, 別の機会に行う こととする. 


\section{4 調 查 結 果}

\section{1 職業とネットワーク}

ファッションはパリを中心とする複数の欧米都市，インダストリアル・デザイン はミラノ，現代アートはニューヨークやロンドンが代表的な場所であり，人のフロ 一が流入する，その理由として，（1）その分野の伝統があり権威ある団体が存在す る，（2）集客力のある大規模な展示会や見本市が定期的に開催される，（3）作者へ の地位付与とイメージ形成の機能があること，があげられている（Crane 1987; Kawamura 2004). 本調查の参加者の場合, 3 名を除く全員が現地の芸術大学・専 門学校の学位またはディプロマ課程で学ぶことを当初の目的として国際移動を行っ ていた，目的地を選択する際には，伝統や教育機関，地位付与機能がその理由とな っていた.

彼ら彼女らが協同的な活動を行うアート・ワールドにおいては, その構成員を職 業・役割から分類できる.ファッションでは，おもに(1)商品のデザインを行うデザ イナー, (2)商品を製作する技術者・職人，(3)広告宣伝を行う PR，ショールーム関 倸者，(4)企業間取引に関わる者（バイヤーなど），(5)消費者への販売を行う者，6 メディアに関わる編集者・記者，に分類される，インダストリアル・デザインでは, この(2)から(4)までのマネージメントをクライアント企業が請け負うことが多い. 現 代アートでは，おもに(1)作品を制作するアーティスト，(2)ギャラリーに所属するア ーティストの広報や作品の売買を行うディーラー, (3)美術館などで展示の企画をす るキュレーター, (4)作品を購入するコレクター, (5)メディアに関わる編集者・記者, 美術評論家， (6)オークションの専門家，に分類される.

現地で活動を開始した後あるいは独立事務所を設立した後，デザイナーにとって は有名なクライアント企業や PR 会社の関係者，アーティストにとっては大手ギャ ラリーの関係者と知り合うことが重要である。なぜなら有力な企業や中間業者と提 携すれば，市場で作品を流通・認知させやすくなるからである，そのきっかけには， 展示会や見本市で作品を発表し仕事のオファーを受ける場合もあるが, 「知り合い の知り合い」など，アート・ワールドで形成される弱い紐帯による紹介が多い.

そして，デザイナー，アーティスト側から見てとくに重要な役割をもつ人々は， 直接的に対価をもたらし収入を左右する人々である。 それは，デザイナーにとって は顧客となるバイヤーやクライアント企業の社員であり，アーティストにとっては ディーラーを介して顧客となる富裕層のコレクターである. たとえば，アーティス トの A さんはコレクターのもつ力について次のように述べる.

A：去年みんなが心配していたのは, 批評の力が弱くなってコレクターが強 くなってる.

筆者：ニューヨークで? 
A : ニューヨークで. うん. だから, 評論家がいいっていうからいいんじゃ ない, コレクター, 要は売れる作品がいい. で, コレクターがキュレーシ ョンするようになっちゃうから. 自分のコレクション. しまいには自分の 美術館が建つようになる5).

そのうえ，有力なバイヤーやコレクターとの取引は重大な波及効果をもたらす. たとえば,「パリの〔セレクトショップの]L'eclaireurって老舗のお店ですし, 海 外のバイヤーさんも見に行くんですよ. L'eclaireurで〔販売されている服を〕見 たけれどっていう問い合わせが〔ほかの店のバイヤーから〕結構来ました」卓「「〔 ユーヨークにはコレクター同士のコミュニティがあるんです. あの人が買ったか

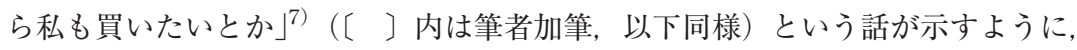
同じ職業・役割をもつ人々がこぞって取引を求めるようになるという。したがって, デザイナー, アーティストにとっては, これらの人々とのネットワーク形成が有利 に働く.

編集者・記者は作者や作品の認知度やイメージを高めるうえで重要な「ゲートキ ーパー」の役割を果たす。 とくにファッション分野はVogue, インダストリアル・ デザイン分野はDomus, Elle Decor, アート分野はArt Forum, The New York Times などが有力なメディアだとみなされている，その影響は「マス」消費者層 に向けたメディアや商品の流行にまで波及する。デザイナー, アーティストにとっ ては, 好意的な記事が掲載されれば「正統性」の承認が促され, グローバルな市場 でも認知されやすくなる，だが調査参加者の大半は欧米メディアの編集者・記者と のネットワーク形成にあまり関心を払っていない. その 1 つの理由は, バイヤーや 企業, コレクターとの関係は短期的・直接的な利益に繫がるが, 編集者・記者が作 者や作品に関する記事を書いても短期的・直接的に収入が増えないからである. た とえば日本の代表的なファッション誌の場合, 「ブッ撮り」のカタログ的, 実用的 な記事が多く（栗田 2007）, 雑誌掲載が売上に繫がりやすい. 他方, 欧米の代表的 なファッション誌は芸術的・ジャーナリズム的な写真や批評を重視する傾向が強く, 雑誌掲載の主要な効果は長期的なイメージ形成であり, 間接的にしか利益に結びつ かないという ${ }^{8)}$. もう 1 つの理由は, デザイナーやアーティストがゲートキーパー の重要性を認識している場合でも, 後述するように, 白人が多数派を占める編集 者・記者とのネットワークに入りにくいからである.

\section{2 人種とジェンダー}

この職業とネットワーク形成を, 人種とジェンダーの観点から見てみると, 特定 の傾向が現れる．まず，ファッション，インダストリアル・デザイン，現代アート すべての分野で「白人」が多数派である. 現在ではデザイナーやアーティストには アジア系などの「有色人種」が増加し一定の地位を確立しているが, とくにバイヤ 一, コレクター, 編集者・記者などの重要な役割は白人が占めている ${ }^{9)}$. また, 女 
性がおもな消費者であるファッション以外では, 男性が多数派で重要な職業・役割 を占めている．この状況が日本出身のデザイナーやアーティストの活動にさまざま な影響を与えていた。

人種の影響に関しては，第 1 に，協同的な活動で障害となる場合がある．たとえ ばロンドンで活動するファッション・デザイナーのC さんは，白人の職人たちに 受け入れられるまでの苦労を語った.

目がこうだよねとか,「何食べてんの」とかそういうことから……ただ私 のデザインは日本人がやっていることだから，ちょっとおかしいというか，ち よっと違うみたいな感じで，批評も受けましたし。……結局私のデザインをや ってかなきゃいけない人なんで，結果的には良い関係にはなったんですけ ど10).

第 2 に，企業との交渉で障害となる傾向がある．たとえばファッション・デザイ ナーの B さんが「結局洋服って西洋の文化でどこかしらアジア人って下に見られ ている。.…駆け引きとかは完全になめられている」11) と述べるように，企業との 取引や契約で不利な立場におかれやすい．第 3 に社交の場で障害となる傾向がある. 先述のとおり，利益を生む活動への参加はしばしばネットワークを介して決定され る. そのため, 展示会でのレセプションやアフターパーティー, 非公式な食事会な どでの社交が重要となってくる．だが調査参加者の半数以上は積極的に参加してい ないか，白人中心の場での社交の難しさについて触れた。 たとえばロンドンで 10 年以上活動しているアーティストの D さんはこう語る.

マイケル・ジャクソンの気持ちはわかるね. ……変だっただろうなと思う. 社交でパーティーとか行ってもさ，どこ座っていいかわかんないしさ，ヨーロ ピアン系の人たちでみんな固まっちゃって話すぐ進んじゃうし.…...なかか 〔白人中心の]それは崩せないよね. その中に入っていくのはやっぱり大変だ から ${ }^{12)}$.

この社交の場での障害には，人種という要因以外にも，言語が関係する．現地で 使用されている公用語の能力がとくに高い者は，「〔アメリカ人が〕知らないことを 知っているんじゃないかっていうふうに思われる感じがするんですよ，そういう意 味では得だと思いますね到 というように，むしろ「日本（人）らしさ」を資源と して利用できる。他方, 公用語でのコミュニケーションに不自由を感じる者には, 社交の場だけでなく，作品のプレゼンテーションや交渉の場でも言語が障害となり やすい. しかし，技術や作品の質が高ければ言語が障害となっても高い評価を受け ることができる，という意見も繰り返し聞かれた。

さらにジェンダーとセクシュアリティが複合的な影響を及ぼす．男性の調査参加 
者によれば，社交において日本人男性は日本人女性よりも不利である。たとえば, 「アジア人の男性が行くとウェルカムされないことがあるんですよ．……とに白 人の男性とか〔自分の存在に〕まったく興味をもたない」14) という話が聞かれた. これは, 白人男性が異性愛者であれば有色人種の女性の「女らしさ」は資源となる が，有色人種の男性の「男らしさ」は脅威となるからである（Espiritu 1997）。 ま た, 男性の同性愛者の割合が高いという話もよく聞かれた. とくにファッション界 ではその傾向が強いという。ニューヨークで活動する男性ファッション・デザイナ ーの Fさんは次のように述べる.

〔自分は〕ストレートな男性なんで非常に不利だと思いますね.コミュニケ ーションもコミュニティにも入れないです.やっぱり〔ファッション界の〕ゲ イのコミュニティは. ……゙イの男性と女性というのは結構うまくやっていけ るんですけど, ゲイの男性とストレートの男性っていうのはあんまりないみた いですね ${ }^{15)}$.

このように，日本人男性が異性愛者であれば，人種の面だけでなく，ジェンダー， セクシュアリティの面でも文化的な近さを有しておらず, 社交や親しい関係の形成 の障害となる.

その一方で，女性側から見れば，女性であることは社交の面では有利になる場合 があっても，企業との交渉や作品の評価に役立たないという。たとえば女性インダ ストリアル・デザイナー $\mathrm{G}$ さんは「イタリア人は女性に優しいという意味では得 してますけど, 実際デザインを出すというところでは得も損もないですね」年) と述 べている. 実際, 女性の調査参加者に「女らしさ」を交涉や作品に戦略的に利用し ようと試みる者はおらず, また女性としてのアイデンティティを強調する者もいな かった. おそらくその 1 つの理由は, 前述のとおり, 交涉や評価など重大な判断が なされる局面では「女らしさ」が資源となりにくいからである.もう 1 つの理由は, 日本社会ですでに女性として周縁化されていたからである. 彼女たちは, 欧米都市 に移動したことで人種の面でも周縁化されるようになった。「何か性別も国籍も人 種も年齢とか, いろんなものがあるので紛れてしまって, 逆に〔女性であること が」気にならないという感じ」17) と女性アーティスト $\mathrm{H}$ さんが話すように, 二重に 周縁化されたことによって，自己意識が人種とジェンダーに分散されたと考えられ る. 他方, 男性の調査参加者の場合, 日本社会では人種・ジェンダーの面で無標で あったが, 欧米に移動し人種の面ではじめて有標化され，人種やジェンダーのカテ ゴリーがもたらす障害に強く意識が向けられたのだろう.

このように白人男性がパワーをもつアート・ワールドでは, 日本出身の人々の間 でネットワークが形成され，相互扶助的な関係が築かれている．パリのファッショ ン界, ニューヨークの現代アート界である程度の経験をもつ日本出身の人々の間で は,「みんな繋がっている」というほど広範囲なネットワークが形成され, 仕事を 
紹介する, 問題の対処をする, 休㗇を共に過ごすなどに役立てられている．また事 務担当, パタンナーなどのアシスタントには日本出身の人々の割合が多い18).

\section{3 創造性と「日本らしさ」の表象}

以上のように，職業とネットワーク形成には，人種とジェンダーが複合的に影響 を与えている。 このような条件のもと, 本調査のデザイナー, アーティストたちは, どのようにナショナル・アイデンティティを表現しているのだろうか. まず, 作品 を制作するうえで重要なことは, 調査参加者が「架空の想定」「新しい価值」「オリ ジナリティ」などの言葉を用いて語った創造性，独創性である．とくに，（おもに 「西洋」における）デザインまたはアートの歴史的なコンテクストを踏まえつつ, 新しい価值をもつ作品を創造することを重要だとみなしている．たとえばインダス トリアル・デザイナーIさんは，「新しいデザイナーとして新しい価值観を世に問 わなければいけないっていう脅迫観念が自分の中ですごくあって」19) と述べている.

つぎに，市場のグローバル化に対応するため，西欧・北米だけでなく，アジア， ロシア, 中東など多様な地域で普遍的に受け入れられる作品を制作することが求め られている。 この意味では, 先行研究が指摘した普遍性＝西洋という図式 (Kondo 1997）はもはや成り立たたなくなってきている. 調査参加者の大半は, 展示会や打 ち合わせのため, 毎年複数の国々を行き来し, 日常的にインターネットを利用して 国境を越えて仕事上のやりとりをしている。また多くの場合，制作，商品の生産， 展示, 販売は複数国に渡って行われている.このような活動を通して, 地域・国ご との市場の趣味（taste）の違いや，その分野の文脈の差の把握に努めながら，世 界各地で受け入れられる作品を制作しようと試みている.

したがって, デザイナー, アーティストとして成功するためには, 独創性と普遍 性という，一見両立しがたい条件を満たす作品を制作しなればならない。これらは 1 点もののアート作品でも, 多数の複製品が製造される日用品やファッション雑貨 のデザインでも，共通して望ましいとされている価值である。これを達成するため の 1 つの方法は，ナショナルなものを表現せずに，独創的な作品を制作することで ある．調査参加者の大半は，日本的なものを作品に表現することを避け，デザイン は形状や素材, アート作品はコンセプトなどの面で新しさや独創性を生み出そうと 試みていた。たとえばインダストリアル・デザイナーのIさんは次のように説明す る.

日本趣味を逆に封じているっていうのは戦略的というかやっぱり，そういう 浅いレベルで仕事したくないっていうのは自分のなかですごくあって．なんか こう，ジャパネスクなものを見せて，「おお，素晴らしい」っていうんだけど， それは単純に違うから, 差異だけで素晴らしいっていってくれるんじゃないか なと思って ${ }^{20)}$. 
この戦略を採る理由は,「日本らしさ」は本質的な伝統文化に結びつけられやす く, 作品の創造性や独創性が否定されやすいからである.ささらに, グローバル化の なかで「西洋」の中心性が摇らぎつつも，これまで白人性が審美的な「標準」とし て位置づけられてきた，そうであれば，「特殊」とみなされる「日本らしさ」の強 調は, 一部のニッチな市場の趣味には合うかもしれないが, 普遍的に受け入れられ る可能性を低めることになる. だがそうであっても, 欧米諸国のナショナルな文化 の表現を試みる傾向も見られない，たとえばファッション・デザイナーの Jさんは, 「国をテーマにすることって少ないので，とくに今回はブリティッシュっぽくとか っていうのはあんまりないですね」21) と話した.

もう 1 つの方法は, 「日本らしさ」を個性として利用しつつも, 普遍的に受け入 れられる作品の制作を試みることである. 3 名のみがこの戦略を採っていた，具体 的には, 欧米の現代的な人物（例：ストリートの人々, 政治家)を題材とした彫刻 や版画に日本の伝統的手法（例：木彫，紅型）を用いる, 西欧で生まれた家具にア ジアの家具の意匠を取り入れるなどの方法を採り，これまでに存在しなかったタイ プの作品を生み出そうとするのである. アーティスト Dさんはこの戦略について, 「日本人らしいことやる方が海外では生きて行けますよって話だよね. 極限状態に 追い詰められたら村上〔隆〕さんだってそうだったはず」22)と説明する，そうであ っても彼らは, 芸者などのエキゾチシズムやオリエンタリズムに訴える「日本らし さ」をけっして用いない.「西洋」のデザインやアートの文脈に, ある種の「日本 らしさ」を融合することで新しい価值を創造し，独創性と普遍性を同時に達成しょ うと試みるのである.

このように, 本調査のデザイナーやアーティストたちは, ナショナルな境界を超 えて, 新しい価值や独創性を生み出そうと努力している. だが, それぞれ作風や個 性が大きく異なる個々の作品を, 本質的な「日本（人）らしさ」と結びつけようと する傾向がある，そのような傾向はまず，白人を中心とするアート・ワールドの構 成員の間で見られた，たとえばニューヨークで活動するアーティストの Eさんは, 空間・線・光をモチーフとした抽象画を制作したときの反応についてこう述べる.

$\mathrm{E} ：$ 日本人的だなっていうアメリカ人もいた．…‥なんかミニマルな日本の, まあ, 日本人だっていうことを知っていっているのかわかんないけど, 「Oh! So Japanese!」とかね.

筆者：それはどなたですか.

$\mathrm{E} ：$ コレクターさんとか一般の人ですね. 何か, こう評論家とかになってく ると, どうしても歴史がドーンと入ってくるんで23).

このように「日本（人）らしさ」と頻繁に関連づけられるおもな要素には，「小 さい」「器用な」「繊細な」「かわいい」などがある. 数人は, 作品の「日本らしさ」 を指摘されるので, 意図的に表現しようとしなくても「日本らしさ」が「にじみ出 
てくる」のではないかと考えていた.

つぎに，前記のような傾向は欧米のメディアにも見られた，先行研究によれば, 欧米メディアが「日本らしさ」を繰り返し強調する 1 つの理由は, 日本人デザイナ 一が際立って創造性の高い「洋服」をつくることを脅威に感じ, 「日本」という本 質的なアイデンティティの枠内に押し込めようとするからだという。その一方で, 欧米出身のデザイナーに「アメリカの」「フランスの」という出身国を表す形容詞 は付きにくい (Kondo 1997)。調查参加者の展示会や作品に関する記事にも, ナシ ヨナリテイを想起させる言葉が用いられていた．たとえばStyle.com ${ }^{24)} に は$ 筆者が インタビューを実施したデザイナーのうち，3名の作品の批評記事が掲載されてい る. 2002 年から 11 年までの計 29 本の記事のうち, 7 本に「Japan」「Japanese」 「kawaii」などの語が使用されていた。 パリで活動するファッション・デザイナー の $\mathrm{K}$ さんは次のように述べる.

やっぱり日本人デザイナーって書かれるので，そこに日本人というフィル夕 一ははじめからあるので．日本人デザイナーが作る服っていうのが先入観とし てあるんですね.コム・デ・ギャルソンとかヨウジ，イッセイさんにちょっと でも似たものがあると汭。

しかし「日本らしさ」の表象は多くの場合，制作者が意眓する表現とはズレがあ り，またその視点によって変化する恣意的なものである，たとえば，ミラノで活動 するインダストリアル・デザイナーの Lさんは，制作した家具のデザインに対す る批評についてこう語る.

イタリアのジャーナリストはものすごくこれは日本的だって評価してきて. フランスの Le Monde も,〔The〕New York Times も皆そういう評価をしてき て、だからなんとなく僕たちにとっては日本的なものなんだっていうふうに. でも同時に日本人のジャーナリストは「やっぱり……すごくイタリアっぽいで すよね」っで26.

この話が示すように，文化的にハイブリッドな作品であれば，見る者の文化的な バックグラウンドや視座に応じて，ナショナルなものの見え方は変化する．白人の 編集者・記者を中心とする欧米メディアの場合，白人性を「標準」とした価值観に 基づき, 審美的な判断を下す傾向が根強い ${ }^{27)}$. さらに, 本調査のデザイナーやア 一ティストの大半にとって, 白人の編集者・記者とネットワークを形成したり, 意 見を交換したりする機会は比較的少なく，その判断に影響を与えることも難し (28)．このような状況のもと，「非白人」のデザイナー, アーティストによる作品 の「日本らしさ」が強調され，ナショナルな境界が画定されているといえるだろう. 


\section{5 結 論}

結論として, アート・ワールドの職業・役割に見られる特徵的な人種関係と, そ の人種関係に基づく作品への評価のあり方が，「日本らしさ」の再構築を促してい るといえるだろう。制作者の「日本らしさ」への愛着によって，ナショナル・アイ デンティティが再生産されているわけではないのである.

すなわち，ファッション，インダストリアル・デザイン，現代アートの各分野で, グローバルなフローの主要な結節点となっているのはいずれもパリ, ミラノ, ニュ ーヨークなどの欧米都市である. 現在では, 先行研究が対象とした先の世代の日本 出身のデザイナーやアーティストの時代と比べて, 国境を越える人のフローが活発 化している. 日本を含むアジア系のデザイナーやアーティストも増加し, その活動 も顕著になっている. 調查参加者たちも, 複数の国々を行き来し, 日常的にインタ 一ネットを利用して, 国境を越える活動を行っている.

この欧米都市のアート・ワールドでは, 弱い紐帯がさまざまな利益を生む活動に 影響を及ぼす。しかし現在でも, バイヤーやコレクター, 記者・編集者など, 重要 な判断や権力を行使する役割においては白人が圧倒的な多数派である. それは現在 人口の 4 割程度が外国生まれとなったニューヨークやロンドンのアート・ワールド でも同様である. そのため, 日本出身のデザイナーやアーティストにとっては, 人 種がネットワーク形成や協同的な活動で障害となりやすい，さらに，白人を中心と するアート・ワールドの構成員には, 白人性を「標準」とした価值観を基に, 「有 色人種」の作家の作品を人種的な, あるいはナショナルなアイデンティティと関連 づける傾向が根強い. だがそれは, 望ましい価值とされている作品の独創性と普遍 性を否定し, 本質的・伝統的なものと結びつける行為でもある ${ }^{29)}$. そして, 各分 野で強い影響力のあるメディアは主に欧米資本の多国籍メディアであり, それらに よって複製される言説やイメージの一部が, 国境を越える情報のフローとなって世 界各地に流布していく.

今後この状況が変わるには，国境を越える文化のフローがいっそう脱中心化・多 極化し，アジアやほかの地域が文化のフローを送出する主要な結節点となっていく ことが必要だろう。また欧米都市のアート・ワールドで, 多様な民族的・文化的バ ックグラウンドをもつ人々が, 重要な判断をくだし権力を行使する役割を獲得する ことが鍵となるだろう。

[付記] 本稿は科学研究費補助金若手研究（B）「文化生産に扔けるトランスナショナル・アイデ ンティティと『日本人らしさ』の構築」(課題番号 21730423 , 研究代表者 藤田結子) による成果の 一部である. 


\section{[注]}

1）「人種」は社会的に構築された身体に文化的意味を与えるカテゴリーである.

2）本稿は一般的に使用されている訳語の「アート・ワールド」を用いるが, ベッカーが示した ように，単一の art world ではなく，複数の art worlds が存在していると考える.

3）グローバルな文化生産で中心的役割を果たす都市については，文化帝国主義的アプローチを 想起させる「中心」という語よりも，人，情報，商品のグローバルなフローが集まる「結節 点」(Appadurai 1996: 31) という語で表すほうが適切だと考える.

4） 2009 年 5 月にロンドン, 09 年 9 月にニューヨーク, 09 年 11 月にロンドン・パリ, 10 年 9 月にニューヨーク， 11 年 3 月にロンドン・パリで調查を行った。また, 09 年 5 月から 12 年 3 月の間, 調查参加者が日本に滞在している時期は東京や地方都市で調查を行った.

5）アーティスト $\mathrm{A}$ さんのインタビュー, 2011 年 3 月 31 日に関東近県で実施した（以下，実施 日と場所のみを表記)。

6）ファッション・デザイナー B さん，2011 年 10 月 26 日，東京.

7）アーティスト $\mathrm{A}$ さん，2011 年 3 月 31 日，関東近県.

8）広報の $X さ$ さん, 2011 年 10 月 26 日, 東京.

9）これは現地の展示会やレセプションなどさまざまな機会に観察された．また，最近の事例研 究でも指摘されている，竹沢 (2009), Mears (2011), Tu（2011）を参照.

10）ファッション・デザイナー $\mathrm{C}$ さん， 2009 年 12 月 29 日，東京.

11）ファッション・デザイナー B さん，2011 年 10 月 26 日，東京.

12）アーティスト D さん，2011 年 3 月 13 日，ロンドン.

13）アーティスト $\mathrm{E} さ ん ん, 2010$ 年 9 月 22 日，ニューヨーク.

14）キュレーター $\mathrm{Y}$ さん，2011 年 8 月，東京.

15）ファッション・デザイナー Fささ，2010 年 9 月 18 日，ニューヨーク。パリまたはロンドン で活動するデザイナーたちからも同様の話が聞かれた.

16）インダストリアル・デザイナー $\mathrm{G}$ さん，2010 年 9 月 2 日，東京.

17）アーティスト $\mathrm{H}$ さん，2010 年 10 月 19 日，東京.

18）「日本人のほうが器用」「文句もいわずに残業する」など生じうるトラブルを回避しやすいこ とがその理由としてあげられた。

19）インダストリアル・デザイナー I さん，2009 年 11 月 18 日， ロンドン.

20）インダストリアル・デザイナーIさん，同上，

21）ファッション・デザイナー J さん， 2009 年 5 月 27 日，ロンドン。

22）アーティスト Dさん，2011 年 3 月 13 日，ロンドン.

23）アーティスト $\mathrm{E} さ ん ， 2010$ 年 9 月 22 日，ニューヨーク.

24）米雑誌Vogue を発行するCondé Nast 社が運営. 欧米のファッション界で広く読まれている.

25）ファッション・デザイナー $\mathrm{K}$ さん, 2011 年 3 月 11 日, パリ.

26）インダストリアル・デザイナー L さん，2010 年 9 月 2 日，東京.

27）この白人中心の価值観が今日でも根強いことは，アート・ワールドの白人の構成員の視点に 関する研究も指摘している，たとえばMears（2011）を参照.

28）たとえばファッション・デザイナーの M さんは，「それについては〔Style.com の記者であ る]彼女からの見方で，たぶん日本人だから kawaiiって書いたりしてるんだろうなっていうぐ らいで．別に意識はしてないです，それは彼女のビジョンなんで」と述べている．2009年 9 月 14 日, ニューヨーク。 
29）そうであれば, 「日本らしさ」を強調する政府のナショナル・ブランディングは, 制作者が 新しい価値を創出しようとする試みを阻む要因となるだろう.

\section{[文献]}

Allison, Ann, 2006, Millennial Monsters, Berkeley: University of California Press.

Appadurai, Arjun, 1996, Modernity at Large, Minneapolis: University of Minnesota Press.

Basch, Linda G., Nina G. Schiller and Cristina S. Blanc, 1994, Nations Unbound, Langhorne: Gordon and Breach.

Becker, Howard S., 1982, Art Worlds, Berkeley: University of California Press.

Castells, Manuel, 1997, The Power of Identity, Oxford / Malden: Blackwell.

Clifford, James, 1986, "Introduction: Partial Truths," James Clifford and George E. Marcus eds., Writing Cultures, Berkeley: University of California Press, 1-26.

Crane, Diana, 1987, The Transformation of the Avant-garde, Chicago: University of Chicago Press. Dyer, Richard, 1997, White, London: Routledge.

Espiritu, Yen Le, 1997, Asian American Women and Men, Thousand Oaks: Sage.

藤田結子，2008，『文化移民一一越境する日本の若者とメディア』新曜社.

Giddens, Anthony, 2000, Runaway World, London: Routledge.

Gupta, Akhil and James Ferguson eds., 1999, Culture, Power, Place, Durham: Duke University Press.

Hannerz, Ulf, 1992, Cultural Complexity, New York: Columbia University Press.

Iwabuchi, Koichi, 2002, Recentering Globalization, Durham: Duke University Press.

Kawamura, Yuniya, 2004, The Japanese Revolution in Paris Fashion, Oxford: Berg.

Kondo, Dorinne, 1997, About Face, New York: Routledge.

栗田宣義, 2007,「モードからストリートへ」『ソシオロジスト』9(1)：213-39.

Lee, Robert G., 1999, Orientals, Philadelphia: Temple University Press.（=2007，貴堂嘉之訳『才 リエンタルズ』岩波書店)。

Marcus, George E., 1995, “Ethnography in/of the World System: The Emergence of Multi-Sited Ethnography," Annual Review of Anthropology, 24: 95-117.

Mears, Ashley, 2011, Pricing Beauty, Berkeley: University of California Press.

成実弘至, 2001,「ファッション・オリエンタリズム」成実弘至編『問いかけるファッション』せ りか書房, 226-51.

Pieterse, Jan Nederveen, 1995, “Globalization as Hybridization,” Mike Featherstone, Scott Lash and Roland Robertson eds., Global Modernities, London: Sage, 45-68.

Sassen, Saskia, 2001, The Global City, 2nd ed., Princeton: Princeton University Press.

佐藤郁哉, 1999, 『現代演劇のフィールドワーク』東京大学出版会.

Schiller, Herbert I., 1969, Mass Communications and American Empire, New York: A. M. Kelley.

Skov, Lise, 1996, "Fashion Trends, Japonisme and Postmodernism," Theory, Culture \& Society, 13 (3) : 129-51.

竹沢泰子, 2009,「ポスト多文化主義における人種とアイデンティティ」竹沢泰子編『人種の表象 と社会的リアリティ』岩波書店, 266-90.

Thornton, Sarah, 2009, Seven Days in the Art World, New York: WW Norton.

Tu, Thuy Linh N., 2011, The Beautiful Generation, Durham: Duke University Press. 
Waters, Mary C., 1999, Black Identities, Cambridge: Harvard University Press.

Yamamoto, Traise, 1999, Masking Selves, Making Subjects, Berkeley: University of California Press. 吉見俊哉, 1999, 『メディア時代の文化社会学』新曜社.

Yoshimoto, Midori, 2005, Into Performance, Brunswick: Rutgers University Press.

吉澤弥生, 2007, 「文化政策と公共性」『社会学評論』58(2)：170-87.

(原稿受付 2011.9.17 揭載決定 2012.9.14)

\title{
The Construction of "Japaneseness" and Cultural Production in Western Cities:
}

An Ethnography of Fashion, Industrial Designers, and Contemporary Artists

\author{
FUJITA, Yuiko \\ Meiji University \\ yfujita@meiji.ac.jp
}

This study explores the process of cultural production in fashion, industrial design, and contemporary art in the era of globalization. It specifically addresses the following research question: “How is 'Japaneseness' constructed in the art worlds in western cities?". To answer this question, I conducted a multi-sited ethnography in London, New York City, Paris, and Tokyo, using participant observation and in-depth interviews with twenty-one designers and artists who had migrated from Japan.

The results indicated that in the art world, being part of a network of people from different professions often leads to corporative activities that result in profits. However, people in positions of power, in particular, buyers, collectors, journalists, and editors, are mostly White, although Asian designers and artists have a stronger presence these days. Therefore, race often becomes an obstacle to networking and partaking in corporative activities in the art world for the designers and artists who were interviewed. Moreover, gatekeepers and legitimators of the art world often refer to the designs and artworks of these designers and artists as having a "Japaneseness" about them, often in conjunction with stereotypical images. In conclusion, networks and interactions, which are influenced by race relations in the art world, lead to the construction of "Japaneseness."

Key words: cultural production, art worlds, national identity

(Received Sep. 17, 2011 / Accepted Sep. 14, 2012) 